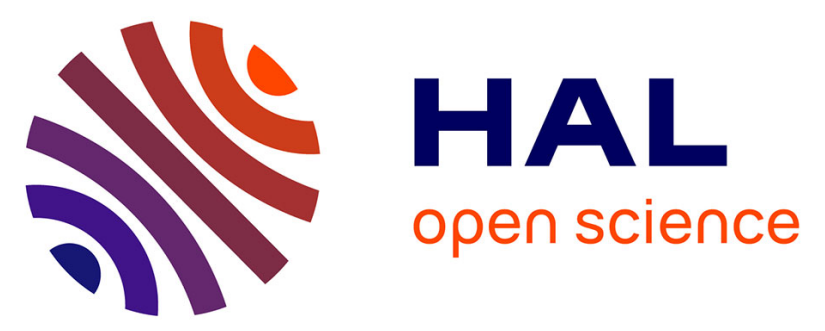

\title{
Charcoal analysis at Limon-Raspail (Vaucluse, Southeastern France): new data concerning the vegetal landscape and its management in Provence at the end of the Neolithic (2880-2580 cal. B.C.)
}

Janet Battentier, Jessie Cauliez, Isabelle Théry-Parisot, Claire Delhon

\section{To cite this version:}

Janet Battentier, Jessie Cauliez, Isabelle Théry-Parisot, Claire Delhon. Charcoal analysis at LimonRaspail (Vaucluse, Southeastern France): new data concerning the vegetal landscape and its management in Provence at the end of the Neolithic (2880-2580 cal. B.C.). Archeosciences, revue d'Archéométrie, 2019, 43 (1), p. 53-68. 10.4000/archeosciences.6192 . hal-01990585

\section{HAL Id: hal-01990585 \\ https://hal-univ-tlse2.archives-ouvertes.fr/hal-01990585}

Submitted on 15 Nov 2021

HAL is a multi-disciplinary open access archive for the deposit and dissemination of scientific research documents, whether they are published or not. The documents may come from teaching and research institutions in France or abroad, or from public or private research centers.
L'archive ouverte pluridisciplinaire HAL, est destinée au dépôt et à la diffusion de documents scientifiques de niveau recherche, publiés ou non, émanant des établissements d'enseignement et de recherche français ou étrangers, des laboratoires publics ou privés. 


\title{
Charcoal Analysis at Limon-Raspail (Vaucluse, Southeastern France): New Data Concerning the Vegetation and its Management in Provence at the End of the Neolithic (2880-2580 cal. B.C.)
}

\author{
Analyse anthracologique du Limon-Raspail (Vaucluse, Sud-Est de la France) : \\ nouvelles données sur la végétation et sa gestion en Provence à la fin du Néolithique \\ (2880-2580 cal. BC)
}

\author{
Janet Battentier ${ }^{a}$, Jessie Cauliez ${ }^{b}$, Isabelle Théry-Parisota et Claire Delhon ${ }^{a}$
}

\begin{abstract}
The charcoal analysis of the Late Neolithic open-air settlement of Limon-Raspail (Southeastern France, 2880-2580 cal. B.C.) documents the vegetal landscape and its management in the Mediterranean hinterland, between the Rhone lower alluvial plain and the alpine foothills, during a period of increasing agro-pastoral pressure and territorial competition. This area at the edge of the Mediterranean influence is poorly documented at this time while the foreland seems concerned by a shift from the primary deciduous oak forest to the evergreen shrubland. The charcoal samples proceed from accumulation in stratified individual and clustered pits used as hearths or middens. The spectrum suggests the importance of the deciduous oak forest and the exploitation of contrasted formations such as supra-mediterranean, mountain, shrubland and more humid vegetation. In the uppermost layers, the significant diversification of the taxa - mainly the shrubland ones - may reflect a slight opening up of the landscape or a change in woody resources supply. The potential biogeographic and socio-economical causes are detailed thanks to a review of the regional anthracological data.

Résumé : L'analyse anthracologique du site de plein-air du Limon-Raspail (Sud-Est de la France, 2880-2580 cal. B. C.) documente le paysage végétal de l'arrière-pays méditerranéen, entre la basse vallée du Rhône et les piémonts alpins et sa gestion par un groupe du Néolithique final, au cours d'une période de pression agro-pastorale et de compétition territoriale croissantes. Cette zone à la marge des influences méditerranéennes reste jusqu'à présent peu documentée, alors que l'on sait que la chênaie caducifoliée primaire de l'avant-pays est progressivement remplacée par des formations arbustives sempervirentes. Les charbons analysés proviennent du remplissage stratifié des fosses, isolées ou groupées, qui ont servi de foyers ou de dépotoirs. Le spectre anthracologique suggère l'importance de la chênaie caducifoliée et l'exploitation de formations végétales variées, supra-méditerranéennes, montagnardes, de garrigues et de milieux plus humides. Dans les niveaux supérieurs, une diversification significative des taxons, surtout ceux des formations arbustives, pourrait refléter une légère ouverture du paysage ou un changement d'aire d'approvisionnement en bois. Les possibles causes de ces changements, d'ordre biogéographique et socio-économique, sont détaillées à la lumière des données anthracologiques disponibles pour la région.
\end{abstract}

Keywords: Late Neolithic, open-air site, Southeastern France, vegetation, wood charcoal.

Mots clés : charbon de bois, Néolithique final, site de plein-air, Sud-Est de la France, végétation.

a Université Côte d'Azur, CNRS, CEPAM, Campus Saint-Jean-d'Angély 3, 24 avenue des Diables-Bleus, 06357 NICE cedex 4, France. (janet.battentier@ cepam.cnrs.fr) (isabelle.thery@cepam.cnrs.fr)(claire.delhon@cepam.cnrs.fr)

b Université Toulouse II, CNRS, TRACES, Maison de la Recherche, 5 allée Antonio-Machado, 31058 ToulousE cedex 9, France. (jessie.cauliez@ univ-tlse2.fr) 


\section{INTRODUCTION}

Limon-Raspail (Bédoin, Vaucluse, Southeastern France) is an open-air site, located at nearly $350 \mathrm{~m}$ a.s.l. in the Mediterranean hinterland (Fig. 1), at the foot of the Mont Ventoux (1912 m a.s.l.), between the lower Rhone alluvial plain and the alpine foothills. It was occupied during the Late Neolithic, between 2880 and 2580 cal. B.C. This region was exploited for agro-pastoral purposes since the Early Neolithic (Cardial culture: 5450-4900 cal. B.C.), and during the Middle and Late Neolithic it was intensively visited as a source of Bedoulian flint. The strategic position of this region, at the crossroads between northern and southern Europe and the Alpine area, also explains its attractiveness in a context of development of the exchange networks during the Middle Neolithic (e.g. Beeching, 2003; Léa, 2005; Binder et al., 2012) and then of their diversification, during the Late Neolithic (Lemercier et al., 2004; Thirault, 2004; Cauliez, 2011).

Around 130 Late Neolithic dwellings have been recorded in the department of Vaucluse (D'Anna, 1995; Lemercier $e t$ al., 2004; Caraglio, 2015). Most of them are not stratified or are only known from ancient excavations. During the Late Neolithic, between 3400 and 2100 cal. B.C., the increasing abundance of polished axes and millstones (Lemercier $e t$ al., 2004), the repeated evidence of the use of animal traction (Blaise, 2010) and the increase of the substitution of the primary deciduous oak forest by evergreen shrubland (TriatLaval, 1979; Vernet \& Thiébault, 1987; Heinz \& Thiébault, 1998) suggest the augmentation of agro-pastoral productions (Heinz et al., 1993; Lemercier et al., 2004; Blaise, 2010) that may be linked to a demographic growth (Bouville, 1980; D'Anna, 1995). For the same period, the finds of many remains of stone or earthen architecture (Beeching, 2003; Lemercier et al., 2004; Lemercier \& Gilabert, 2009), the long-lasting settlements of several open-air sites (Blaise, 2005) and the megalithic burials may illustrate an increasing anchorage to the ground (Beeching, 2003; Cauliez, 2011). In the same way, the reinforcement of signs of belonging (anthropomorphic art) and the technical advances (for example in copper metallurgy) may indicate a higher social, economic and territorial competition (Cauliez, 2011).

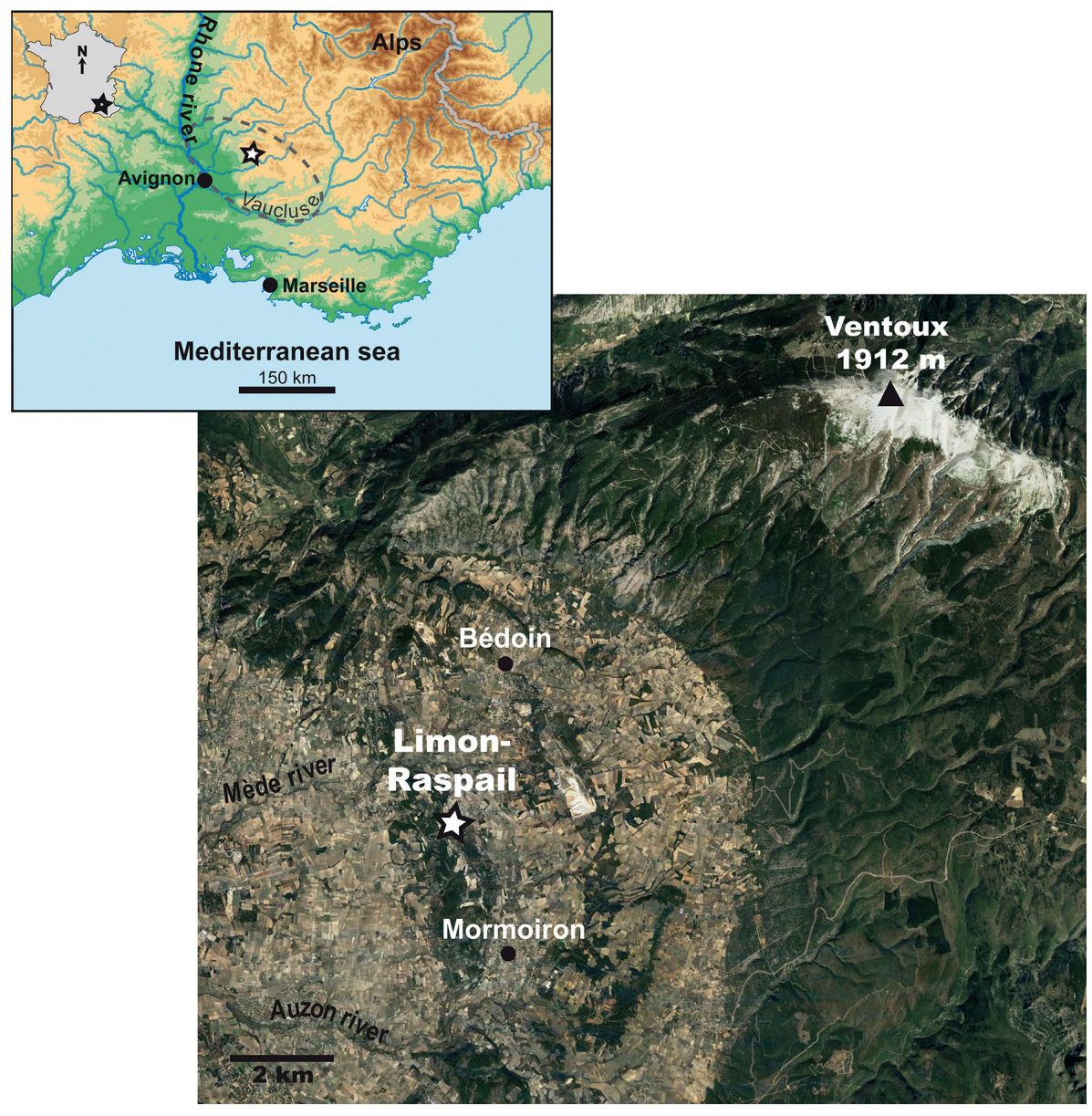

Figure 1: Geographical situation of the Limon-Raspail site (star) in Provence (South-Eastern France). Dotted line: Vaucluse department (C) Google Earth Pro).

Figure 1 : Situation géographique du site du Limon-Raspail (étoile) en Provence (Sud-Est de la France). Ligne pointillée : département du Vaucluse (C) Google Earth Pro). 
Firewood management is often one of the best recorded aspects of the interaction between past societies and their vegetal landscape, because of the important amounts of longlasting remains it provides in the form of wood charcoal. Nevertheless, it remains surprisingly under documented for the end of the Neolithic in the area. The lack of information for the final Neolithic prevents us from clearly understanding the timing and the mechanism of the response of Mediterranean woodland at a pivotal period for the socionatural interactions in a key area, characterized by an already long tradition of natural resources exploitation. Therefore, the recovery of charcoal fragments during the excavations at Limon-Raspail constituted an opportunity to improve the documentation concerning the final Neolithic vegetation in Provence and its management by human populations, and to take another step towards a future synthesis on a regional scale with high chronological resolution, which is currently unattainable on the basis of the available data.

\section{Archaeological setting of the Site}

The Limon-Raspail site was discovered in 2005, during grapevine replanting. The overall area of the site, assessed from the remains recovered in abundance through surveys, reaches $1.5 \mathrm{ha}$, among which $250 \mathrm{~m}^{2}$ have been excavated under the supervision of J. Cauliez. On that surface
35 pits were found, among which 22 have been completely excavated and 16 have been sampled for archaeobotanical investigations (Fig. 2). Six ${ }^{14} \mathrm{C}$ datings carried out on charcoal fragments and animal bones from the pits (Table 1) fit between 2880 and 2580 cal. B.C. (Cauliez et al., 2011), which corresponds to a plateau of the radiocarbon calibration curve (Reimer et al., 2013).

This domestic settlement is located at the foothill of the Mont Ventoux (Fig. 1), whose summit (at $14 \mathrm{kms}$ as the crow flies) is directly visible from the site. The site is located at the interface between argillaceous limestone and Burdigalian molasse, on top of a small hill (350 m a.s.l.) overlooking the sedimentary basin of the Rhone river to the West and the Mormoiron-Bédoin basin to the east. Currently, two rivers traverse this hill: the rivers Auzon (around $4 \mathrm{~km}$ to the south) and Mède (around $1 \mathrm{~km}$ to the north). The low slope declivity and the important sedimentary covering enable a good preservation of the archaeological remains.

Indeed, although the occupation layer and the uppermost layers of the pits have vanished due to the intensive tillage, the remaining infillings of the hollow structures display various and numerous remains documenting the dwellers' way of life. The 22 excavated pits form two groups separated by an empty space. The southern group is composed of individual pits, in a more or less parallel arrangement, whereas the pits are clustered in the northern group
Figure 2: (See colour plate VI) Plan of the excavated area showing the location of the studied pits, with a zoom on structure 23 (clustered pits) showing the successive hollowing phases and a photograph of pit 4 showing the typical filling of a refuse pit (drawings and photos $\mathrm{J}$. Cauliez).

Figure 2: (Voir planche couleur VI) Plan de la zone fouillée et localisation des fosses étudiées, avec un zoom sur la structure 23 (fosses groupées) montrant les phases successives de creusement et photographie de la fosse 4 montrant le remplissage typique d'une fosse de rejet (dessins et photographies J. Cauliez).

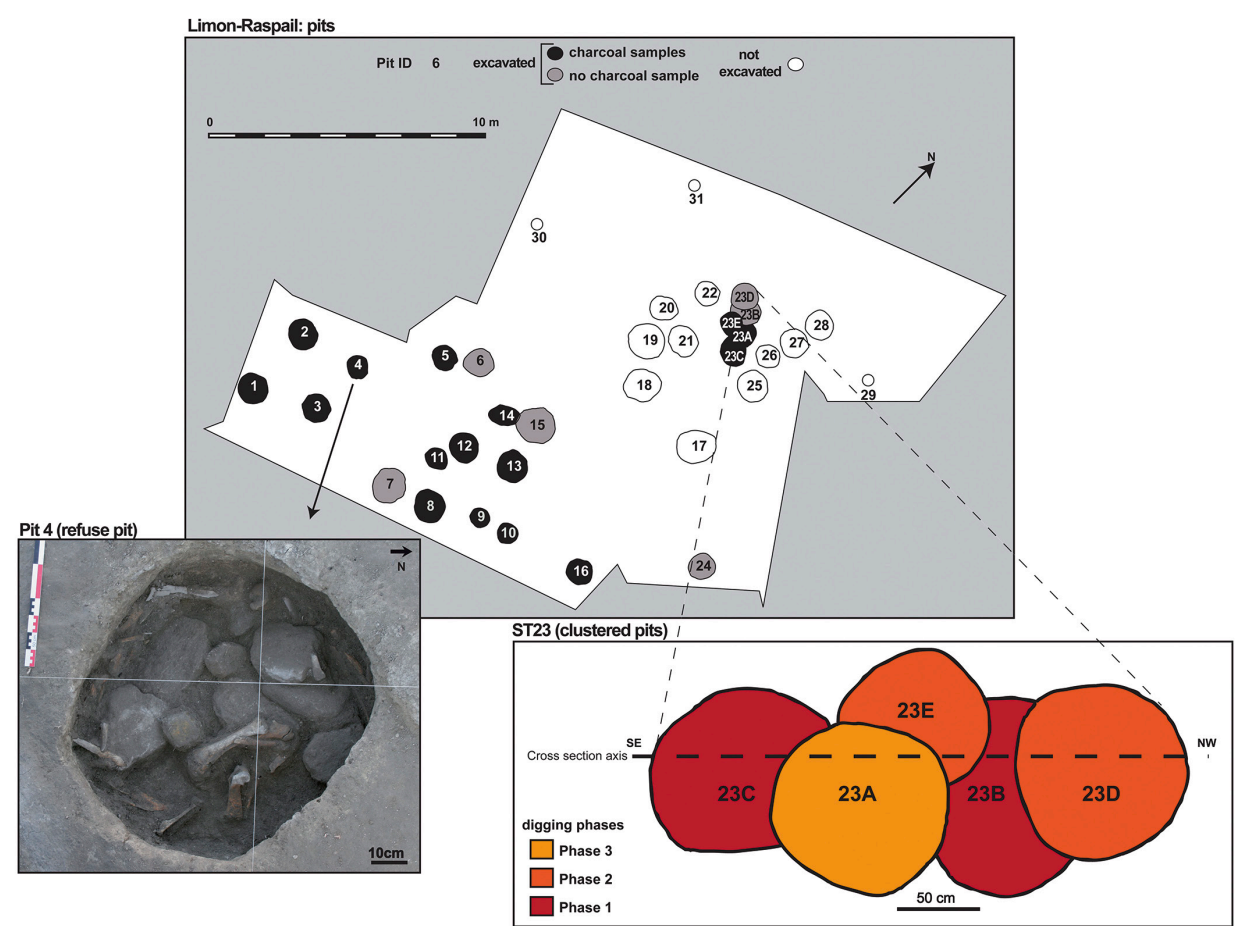




\begin{tabular}{|c|c|c|c|c|}
\hline Pits & Layers & Lab code & B.P. & cal. B.C. $(2 \sigma)$ \\
\hline 4 & 5 & Lyon-4910 & $4145 \pm 35$ & $2877-2620$ \\
\hline 7 & 5 & Poz-16631 & $4140 \pm 35$ & $2875-2601$ \\
\hline 8 & 5 & Lyon-3806 & $4160 \pm 30$ & $2880-2632$ \\
\hline 16 & 10 & Lyon-4911 & $4130 \pm 35$ & $2872-2582$ \\
\hline $23 \mathrm{~A}$ & 8 & Lyon-3805 & $4180 \pm 30$ & $2887-2666$ \\
\hline $23 \mathrm{~B}$ & 3 & Lyon-4912 & $4170 \pm 35$ & $2885-2632$ \\
\hline
\end{tabular}

Table 1: Date B.P. and calibrated B.C. Calibration curve IntCal 13, software OxCal 4.2.4 (Reimer et al., 2013)

Tableau 1: Dates B.P. et calibrées B.C. Courbe de calibration IntCal 13, software OxCal 4.2.4 (Reimer et al., 2013)

(Fig. 2). Contrary to the isolated pits, a relative chronology of the hollowing and use of the clustered pits provides an approximate estimation of the duration of the occupation. The infilling of the pits and their morphology, studied by J. Cauliez and her team (Cauliez et al., 2011), made it possible to distinguish their primary function (mainly that of storage and combustion) and to state that most of them were later used as refuse pits. Among the refuse content, the presence of millstones (fragmented or not), bones of sheep, goat and cattle (Cauliez et al., 2011) and cereal grains (discovered during the sieving but not yet analysed) allows to establish that agro-pastoral and domestic activities were carried out on the site. The age-at-death of domestic ruminants are varied and include young animals, suggesting that the site were occupied in all seasons. Remains of earthen and wooden (wattle) architecture are also present. The ceramic artefacts, show no stylistic evolution during the occupation. The style is influenced by the cultures from regions situated to the North (Drôme: Allan group, Jura and Suisse: Clairvaux group) and to the West (Ardèche: Bruyères group) and to a lesser extent by those that developed in Southeastern France (Provence: Couronnian group), which is probably linked to the location of this site close to the middle Rhone valley which constitutes a major north-south communication axis. The integration of the site within exchange networks is also confirmed by the presence of a fragment of a Pressignien dagger (sourcing from central western France) and the use of alpine rocks such as eclogite and jadeite (Cauliez et al., 2011). Some of the individual pits investigated (pits 1, 2, $3,4,5,8$ and 14) were established as having been refuse pits on the basis of their morphology and the nature of the remains they contained (e.g. butchery refuse: Fig. 2). Pits 9 and 12 present in situ or collapsed pieces of heated earth. They also contain a bottom ashy layer covered by in situ fractured stones, probably under the influence of heat. All these elements have been considered as indicators of combustion pits. The clustered pits $23 \mathrm{~A}$ to $23 \mathrm{E}$ recut each other and thus three successive phases of hollowing were identified
(Fig. 2). The date of pit 23B level 3, from the first phase, is extremely close to the date of pit 23A level 8 , from the third phase (1), but their functions imply that a certain interval of time has elapsed between their respective uses. Indeed, the last pit (23A), which was initially a storage pit, was partly dug into the fill of refuse pits from previous phases (23B and 23E). Storing in a midden seems only possible if its previous contents is sufficiently old to seem clean or at least favourable to storage. According to this archaeological record, Limon-Raspail would not be an occasional occupation and would have either lasted for several years or been reoccupied several times, although both chronocultural and radiocarbon data fail in documenting the precise chronology of the occupation (no ceramic stylistic evolution, overlapping calibrated ${ }^{14} \mathrm{C}$ datings).

Most of the excavated pits presented clearly identified charcoal accumulations. No refitting of the fragments of archaeological artefacts was possible neither between different pits nor between two layers from a same pit, which suggests that the wastes were thrown in the refuse pits directly after their abandonment (Last, 1998), without the use of an intermediary midden (Salavert, 2010; Bosquet, 2013). In this case, the overlapping layers which composed the filling of these pits can be reasonably considered as chronological succession, recording the evolution of the dwellers' way of life (Needham \& Spence, 1997) and, regarding the charcoal wastes, that of the fuel they used (Salavert, 2010).

\section{Current environmental Setting OF THE SITE}

The vegetation around the site currently belongs to the meso-mediterranean vegetation belt. A botanical survey carried out in spring 2015 enabled us to observe that the direct surrounding of the site (currently covered by a vineyard) is occupied by the Mediterranean shrubland dominated by evergreen oak (Quercus ilex) and juniper (Juniperus oxycedrus). Abandoned vine crops are overgrown with a shrubby vegetation-consisting of kermes oak (Quercus coccifera), blackthorn (Prunus spinosa), whitebeam (Sorbus aria)— among which young deciduous oak (Quercus pubescens) and resprouts of olive tree (Olea europaea) are found. This relatively open vegetation includes a bush layer of thyme (Thymus), dogwood (Cornus sanguinea), wild asparagus (Asparagus acutifolius) and sub-spontaneous or post-cultural grape vine (Vitis vinifera). Aleppo pine (Pinus halepensis) and maritime pine (Pinus pinaster) are the only taxa currently represented by fully grown high trees. 
To the north-east, the Mont Ventoux, displays an altitudinal succession of vegetation belts, from the meso- and supramediterranean levels to the mountain and pre-alpine ones (Gobert \& Pautou, 1969). The east-west orientation of the Ventoux determines the presence on its northern slopes of a medio-european vegetation mainly characterised by beechfir association (Fagus and Abies), whereas a mediterranean vegetation mainly represented by deciduous oak and Scots pine (Pinus sylvestris) grows on the southern slopes (Barbero \& Quézel, 1975). However, the Ventoux vegetal landscapes mainly proceed from reforesting carried out since 1861 in order to prevent an alarming deforestation already noticed in 1549 (Guende \& Barbero, 1978) and partly resulting from a high agro-pastoral pressure (Carmantrand, 1955; Thinon, 2007).

\section{Material AND Methods}

During the rescue excavation the anthracological samples were carried out in the 16 stratified pits which present the most complex infilling (Fig. 2). They provided charcoal assemblages from 31 stratigraphic units. Charcoal fragments were recovered in the laboratory by sieving, using flotation, 10 litres of sediment through a $2 \mathrm{~mm}$ meshed sieve for each sample.

The taxonomic identification of the charred wood fragments was carried out with a reflection microscope, at magnifications ranging from 50x to 500x. After being manually fractured, the three characteristic anatomical planes (transversal, longitudinal tangential and longitudinal radial) of the fragments were observed and compared to published descriptions (Schweingruber, 1990; Vernet et al., 2001) and with charred wood from the reference collection of the CEPAM laboratory (UMR 7264, CNRS, Université Côte d'Azur). For each sample, the analysis continued until a further 50 fragments did not allow identifying any new taxon.

To interpret the results of this analysis we have calculated the percentage of fragments per taxa (Table 2; Fig. 3A). In order to reduce the over-representation of the dominant taxa this conventional calculation has been completed by the percentage of occurrences per taxa (Table 3; Fig. 3B). The percentage of occurrences enables to perceive the diversity of taxa in each sample without taking into account the number of fragments from these taxa (Delhon, 2016). In this method "the presence of a taxon in a sample has a value of 1 , whatever the number of fragments of that taxon. The absence of a taxon in a sample has a value of 0 " (Delhon $\&$ Thiébault, 2008 , p. 67). The base sum for the calculation of percen-

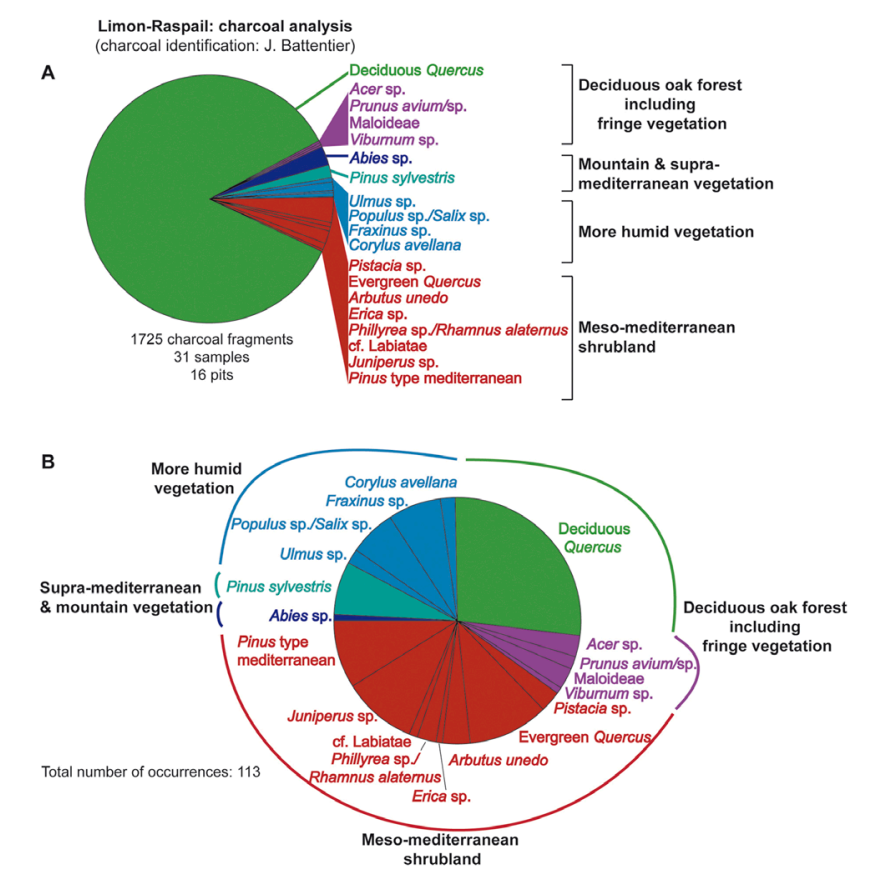

Figure 3: (See colour plate VI) Pie chart of the general results of the charcoal analysis of Limon-Raspail (all pits taken together). Taxa are grouped according to their ecological affinities. A: percentage of fragments per taxa (see table 2 for details). B: percentage of occurrences per taxa (see table 3 for details).

Figure 3: (Voir planche couleur VI) Diagramme circulaire des résultats généraux de l'analyse anthracologique du Limon-Raspail (toutes structures confondues). Les taxons sont groupés en fonction de leurs affinités écologiques. $A$ : pourcentage de fragments par taxon (pour le détail des résultats se reporter au tableau 2). B : pourcentage d'occurrences par taxon (pour le détail des résultats se reporter au tableau 3).

tages is obtained by adding the presences for each sample. The percentages are calculated for each samples by taking into account the number of presence of each taxon and, as base sum, the sum of occurrences per sample. The same method is used to perform the percentage of occurrences for the whole corpus, all pits taken together, with the number of presence of each taxon and as base sum, the global sum of occurrences.

\section{Results}

Most of the 1725 identified fragments offered well-preserved anatomical structures. Almost half of the 31 stratigraphic units exceeded 50 fragments (Table 2). Nineteen woody taxa were identified on the site (Fig. 3), but half of the assemblages provided only 3 taxa or less. 


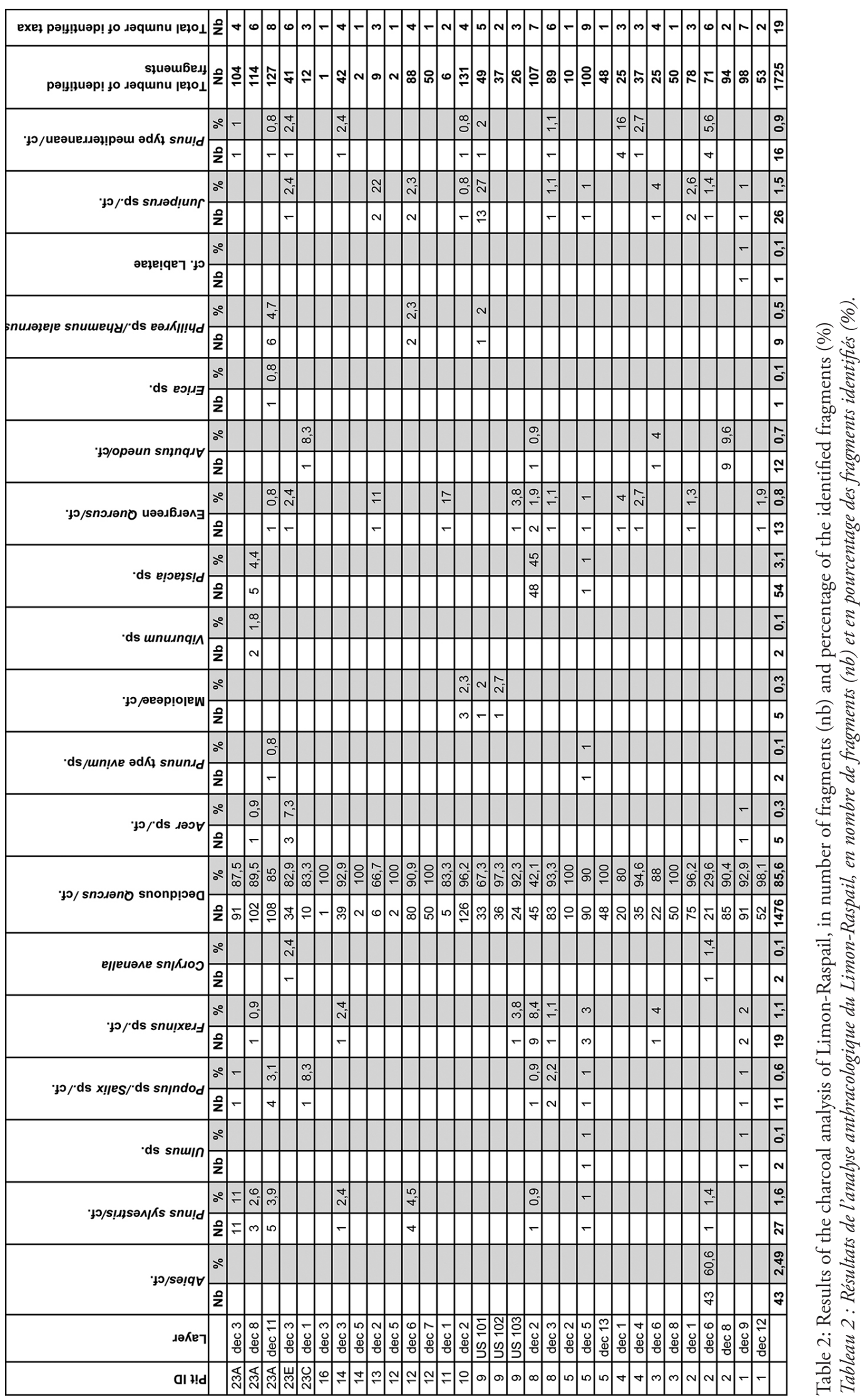




\section{Identified taxa and related vegetation}

Deciduous oak (probably Quercus pubescens in this region) largely dominates the spectrum both in terms of percentage of fragments per taxa (Fig. 3A, Table 2) and in terms of percentage of occurrences per taxa (Fig. 3B, Table 3 ). Regardless of the provenance of the sample, be it from a refuse or a combustion pit as well as from an individual or a clustered pit, the deciduous oak dominates each stratigraphic units. This taxon is the leader of the deciduous oak forest which is the climax of the ecological succession of mesoand supra-mediterranean vegetation belts. The deciduous oak forest includes fringe or understory vegetation, represented in the spectrum by Acer sp., the Rosaceae (Prunus avium, Prunus sp. and the Maloideae) and Viburnum sp. The mountain vegetation is represented by Abies sp. This taxon currently grows above $1200 \mathrm{~m}$ on the northern slope of the Ventoux (Gobert \& Pautou, 1968). Nevertheless, it was probably more widespread at lower altitude during the Neolithic in the north-western Mediterranean according to pollen data (Muller et al., 2007; Magri et al., 2015; Battentier et al., 2018).

Pinus sylvestris represents the supra-mediterranean vegetation. Ulmus sp., Populus sp. or Salix sp., Fraxinus sp. and Corylus avellana represent the more humid or riparian vegetation. Finally, the meso-mediterranean shrubland is represented by a wide diversity of taxa such as Pistacia sp., evergreen Quercus, Arbutus unedo, Erica sp., Phillyrea sp. and/or Rhamnus alaternus, the Labiatae, Juniperus sp. and Mediterranean Pinus.

\section{Diversity of the samples}

Despite the general dominance of deciduous oak, the uppermost levels of the individual pits tend to present a wider taxonomic diversity than the lower ones, notably regarding shrubland species (Fig. 4). However, it must be noticed that they also offered more charcoal fragments than the underlying ones. In order to check if the increasing number of different taxa in the uppermost levels is related to the greater number of charcoal fragments identified, the Shannon and Weaver index $(\mathrm{H})$ has been calculated whenever the diversity exceeded one taxon (Fig. 5). The Shannon and Weaver index (Shannon, 1948; Shannon \& Weaver, 1963) expresses the taxon richness (number of taxa) and their distribution (evenness), relatively regardless of the sample size. It has the advantage of being sensitive to the taxa which are weakly represented. In most of the individual refuse or combustion pits, the Shannon and Weaver indexes of the uppermost or middle layers are higher than those of the lowermost layers, indicating that the taxonomic diversity of the uppermost layers is in general significantly higher than that of the lowermost ones (and, consequently, the evenness is better too). The reliability of the Shannon index variation between two layers of the same pit has been checked thanks to a Mann and Withney test (a nonparametric test appropriate for the comparison of small independent samples). At a $2.5 \%$ risk threshold, it proved to be significant in any case. Thus, the greater diversity of taxa shown by the uppermost layers comparatively to underlying layers is not linked to their higher number of charcoal fragments.

If we consider the anthracological results of the clustered pits (23C, 23E, 23A) as a diachronic record spreading over three phases (Fig. 4), the evolution towards a higher diversity of taxa and a higher abundance of charcoal fragments is clearer. The relevance of the increasing diversity was tested using the Shannon and Weaver index (Fig. 5). In this case too, the values of the Shannon-Weaver index are higher in the uppermost layers than in the lowermost ones which indicates that the diversity is indeed increasing through time, independently to the sample size. The Mann and Withney test (with a 2.5\% risk threshold) has checked that the $\mathrm{H}$ variation between two of these pits is always significant.

\section{Discussion}

\section{Paleoenvironment}

The analysis focus on pits used as hearths or where charcoal was dumped after the cleaning of hearths. These deposits are related to a short time of accumulation and could possibly be too occasional to be representative of the whole diversity of the paleoenvironment when they are considered individually, as shown by the low number of taxa per sample (Table 2). However, investigating numerous pits layers, each of them resulting from a short-term accumulation, does allow the obtaining of a broader spectrum (Chabal, 1997; Théry-Parisot et al., 2010).

The paleoenvironmental interpretation is authorized by the ecological coherence of the spectrum, and the fact that it is consistent with the local ecological conditions. The predominance of deciduous oak associated to fringe taxa belonging to the understory vegetation (Acer sp., Viburnum sp. and the Rosaceae) suggest the importance of the deciduous oak forest.

The diversity of the xerophile shrubland vegetation refers to an open vegetation growing on dry ground, contrary to the mesophilic deciduous oak forest and the meso-hygro- 


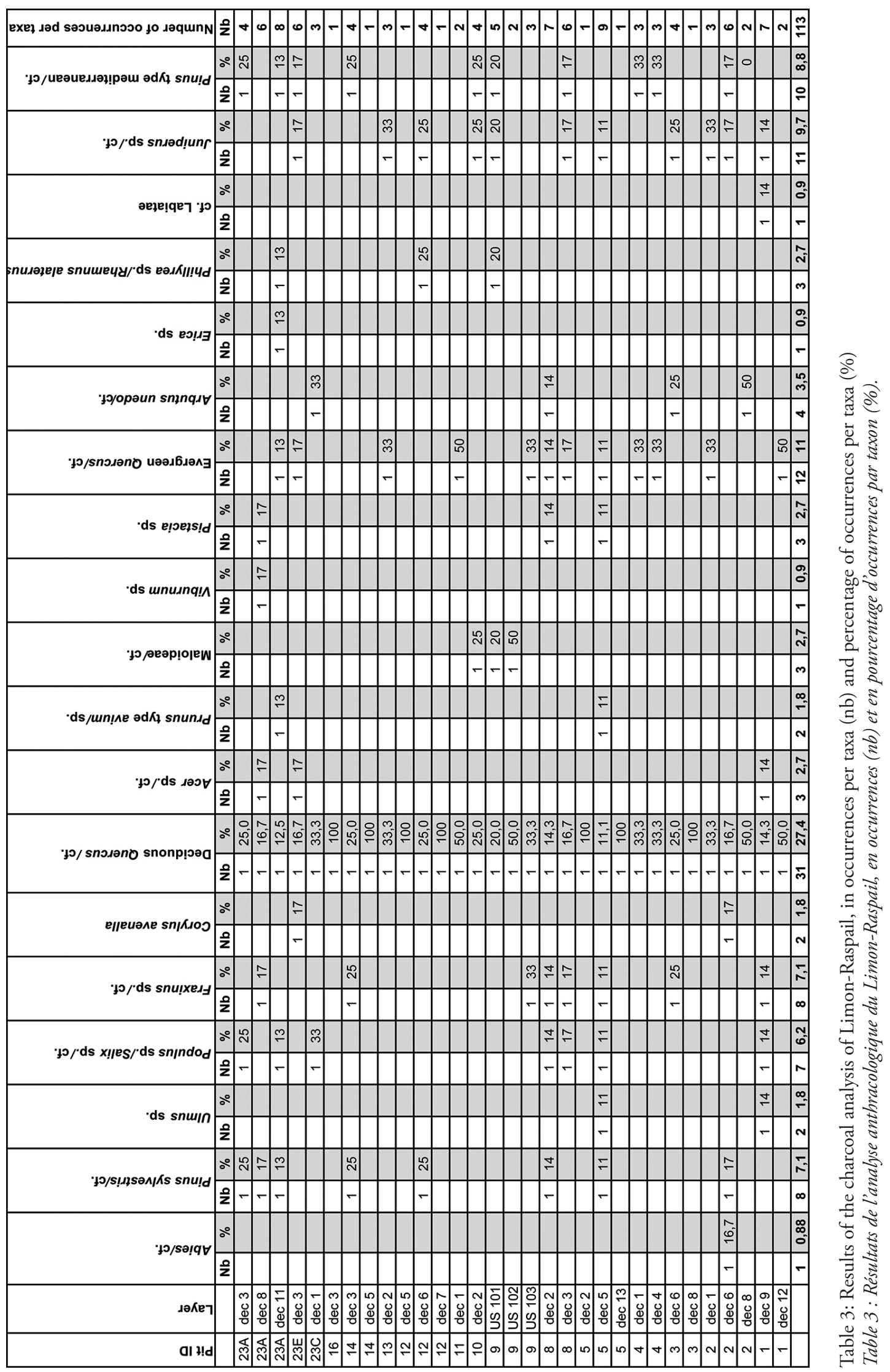


Figure 4: (See colour plate VII) Anthracological histograms (percentage of fragments per taxon) of the pits according to the stratigraphy (see table 2 for details). Nb: number of identified fragments; black line: 95\% confidence interval.

Figure 4: (Voir planche couleur VII) Diagrammes anthracologiques (en pourcentage $d u$ nombre de fragments par taxon) des fosses selon la stratigraphie (pour le détail des résultats se reporter au tableau 2). $\mathrm{Nb}$ : effectif de fragments identifiés; ligne noire : intervalle de confiance à $95 \%$.
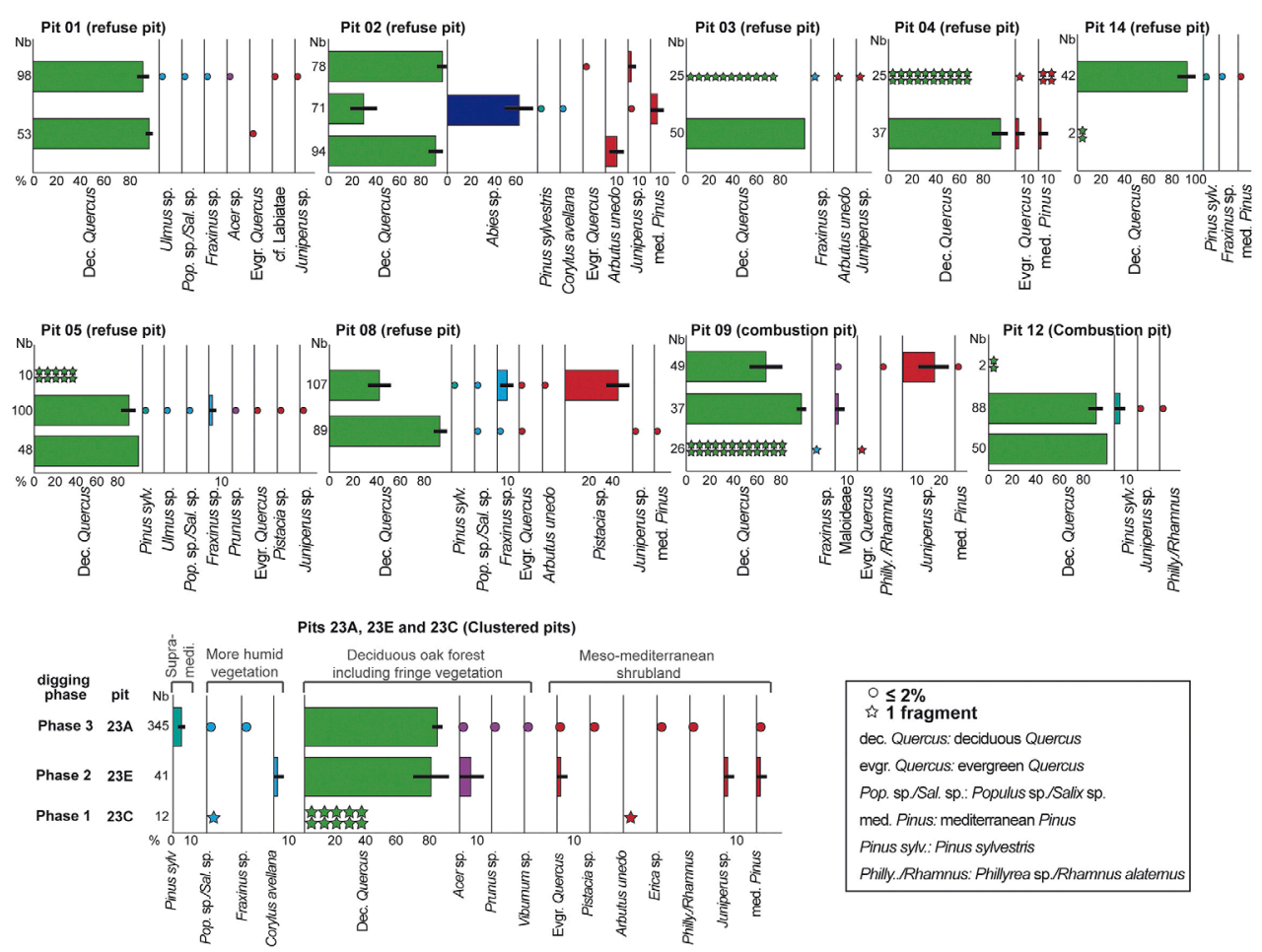
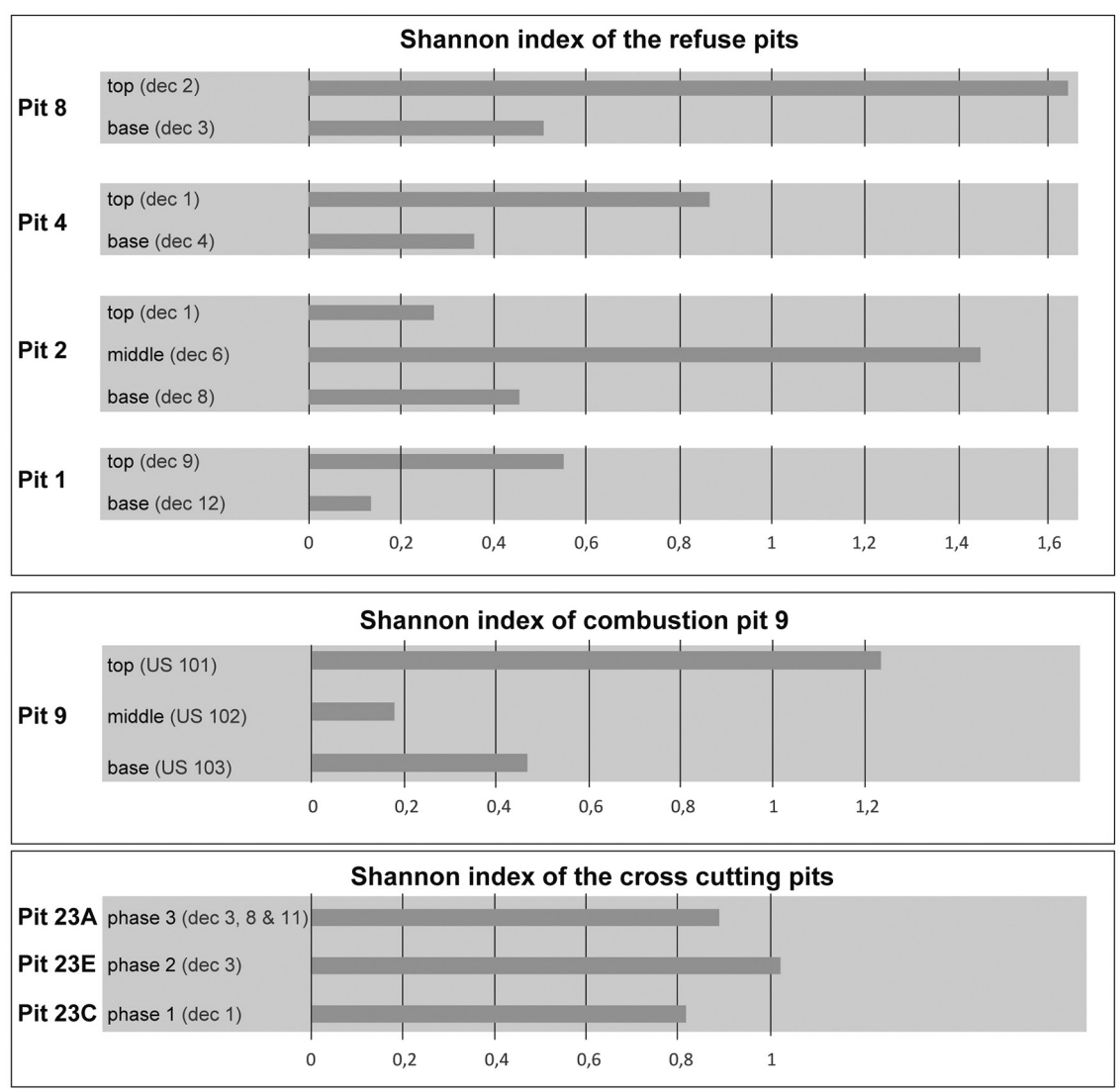

Shannon index $\mathrm{H}=-\Sigma(\mathrm{pi}: \mathrm{pn}) \mathrm{pi}^{\star} \log 2(\mathrm{pi})$

$n$ : number of fragments per taxa, $N$ : total number of fragments per sample, $P i: n / N$
Figure 5: Shannon index values of the refuse, combustion and clustered pits, whenever the diversity exceeded one taxon.

Figure 5 : Valeurs de l'indice de Shannon pour les fosses de rejet, de combustion et les fosses groupées dont la diversité était supérieure à un taxon. 
phile taxa such as Ulmus sp., Populus sp./Salix sp., Fraxinus sp., Corylus avellana. Abies sp. can also refer to vegetal formations growing on rather wet soils and to contexts characterised by sufficient air humidity, provided either by microclimatic condition or/and by closed canopy.

Although deciduous oak is dominant, which is probably due to the primordial importance of the deciduous oak forest in the vegetal landscape, the global percentage of occurrences per taxa (Fig. 3B) seems to be representative of contrasted formations surrounding the site and frequented for the fuel supply. Among the formations which coexist in the local landscape, the meso-hygrophile taxa may grow close to the rivers or the humid area. The deciduous oak forest was probably where the soil was deep or little affected by human activities contrary to the xerophile shrubland vegetation which develops on dry and poor soils (e.g. slopes, most exploited areas). However, since the edaphic conditions remain unknown, it is difficult to be more precise about the organisation of the vegetal landscape.

\section{Land management}

In most of the sampled layers from the refuse and the combustion pits, different formations are represented (Table 2 and Fig. 4). Species from deciduous oak forest, shrubland and more humid formations are often present in the same level. In some layers, besides these associations, mountain and supra-mediterranean vegetation are also represented (pits 2, 5, 8, 12 and 14).

Whatever the functions of the pits are (refuse or combustion pits), several formations - sometimes very contrasted - are exploited. The diversified spectra recorded in most of the pits layers allows to hypothesize the existence of a mosaic landscape within the fuel gathering territory as shown by the percentage of occurrences per taxa (Table 3; Fig. 3B). Furthermore, the increase in the number of shrubland species in the upper levels of each pits showing stratified fills (Fig. 4) may suggest a change of the fuel gathering area towards more open areas of the landscape or a management of the exploited vegetation leading - either voluntarily or otherwise - to the opening up of the landscape. This opening may be due to browsing, repeated trampling by livestock and agro-pastoral fires since bones of domestic ruminants discovered on the site and cereal grains bring evidence of farming and breeding activities. Several of these mechanisms may be superimposed but reliable data (anthropogenic pollen indicators, frequency of the macro-charcoal) are lacking in this area, to precise the cause of the opening up of the landscape. Moreover, the radiocarbon curve plateau hinders the perception of the time it took to fill the pits and thus prevents us from grasping whether it was sufficient or not to allow a vegetation change.

\section{Tracking vegetation changes}

Data from the clustered pits offer a diachronic record during several phases of the occupation of the site, which indicates that the meso-mediterranean shrubland, but also fringe vegetation linked to deciduous oak forest and the more humid formation, tend to diversify at the end of the sequence. This evolution may result from several causes. In particular, the effect of human activities on the vegetation must be considered, as the Vaucluse region has been intensively frequented during the Neolithic (Fig. 6). Farming activities are attested since the Early Neolithic Cardial period either directly by the identification of cereal grains and bones of domestic ruminants or indirectly, through the discovery of millstones (Binder \& Sénépart, 2004). Several sites distributed over the Middle, Recent and Late Neolithic suggest an early and relatively intense agro-pastoral exploitation, which is more widely documented throughout the middle Rhone valley (Delhon et al., 2009). Furthermore, the Vaucluse region was also visited for its lithic resources mainly during the Middle Neolithic. Indeed, several nearby sites (Saint-Martin, les Trois Termes, Rocalibert, La Combe, l'Abri du Levant de Léaunier and l'Abri Grangeon) seem to be knapping workshops, specialized in the production of the bedoulian flint bladelets, which were widely used during the Chassean Middle Neolithic in the whole north-western Mediterranean area. This production, which was a large scale one, often needed heat treatment to improve the pressure process leading to flint bladelets (Léa, 2005; Roqué-Rosell et al., 2011). Thus, this production depended on the use of fuel, most likely in the form of wood. The quantification of the amount of wood consumed for such activity has never been attempted so far to our knowledge, but this activity, among others necessary to the daily-life of the groups that exploited the flint resources, might also have played a cumulative part in the local pressure on the woody resources, several centuries before the occupation of Limon-Raspail. Thus, after three millennia of Neolithic use of the landscape added to a relatively warm, dry and contrasted climate until ca 4500 cal. B.P. (Digerfeldt et al., 1997; Magny et al., 2009; Brisset et al., 2013), the resilience of the deciduous oak forest may have been somewhat lowered.

On a broader scale, the diversification of the shrubland taxa is also recorded on most of the Southern France Late Neolithic sites (Fig. 7). Indeed, from the coastal edge to the inland, the Meso-mediterranean shrubland is either the main vegetation recorded in the anthracological spectra 


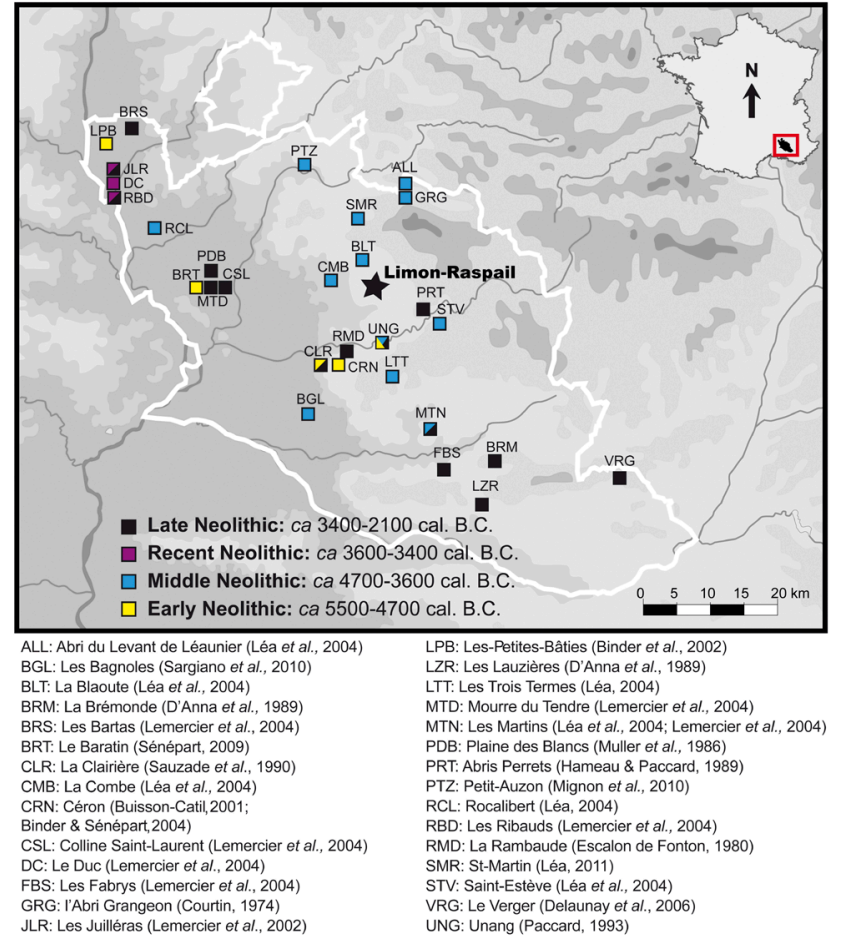

Figure 6: (See colour plate VIII) Main Neolithic sites in the Vaucluse department.

Figure 6: (Voir planche couleur VIII) Principaux sites néolithiques dans le département du Vaucluse.

or it is co-dominant with deciduous oak forest. Charcoal and pollen investigations record the development, since the Middle Neolithic, of the evergreen oak and other sclerophyllous species adapted to dry and shallow soils, to the detriment of the deciduous oak forest (Triat-Laval, 1979; Vernet \& Thiébault, 1987; Heinz \& Thiébault, 1998). These taxa, such as Arbutus unedo, Erica arborea, Pistacia lentiscus, mediterranean Pinus (probably Pinus halepensis in this region) but also Juniperus sp., Phyllirea sp./Rhamnus alaternus, Olea europea and Buxus sempervirens, increase during the Late Neolithic. They are able to grow in coppices and are most of the time light demanding, thermophilous and xerophilous (Rameau et al., 2008) whereas the deciduous oak is more mesophilic. The development of the sclerophyllous vegetation to the detriment of the deciduous oak is greater (and earlier) when the settlements are closer to the Mediterranean (Thiébault, 1991; Battentier, 2018). Indeed, the seasonal contrasts that characterize the Mediterranean climate and the often-steep topography which favour erosion seem to enhance the impact of the agro-pastoral activities on the forest, causing the opening up of the land (Thiébault, 1991; Heinz \& Thiébault, 1998; Battentier et al., 2015). Moreover, in the coastal regions, the anthropogenic pressure

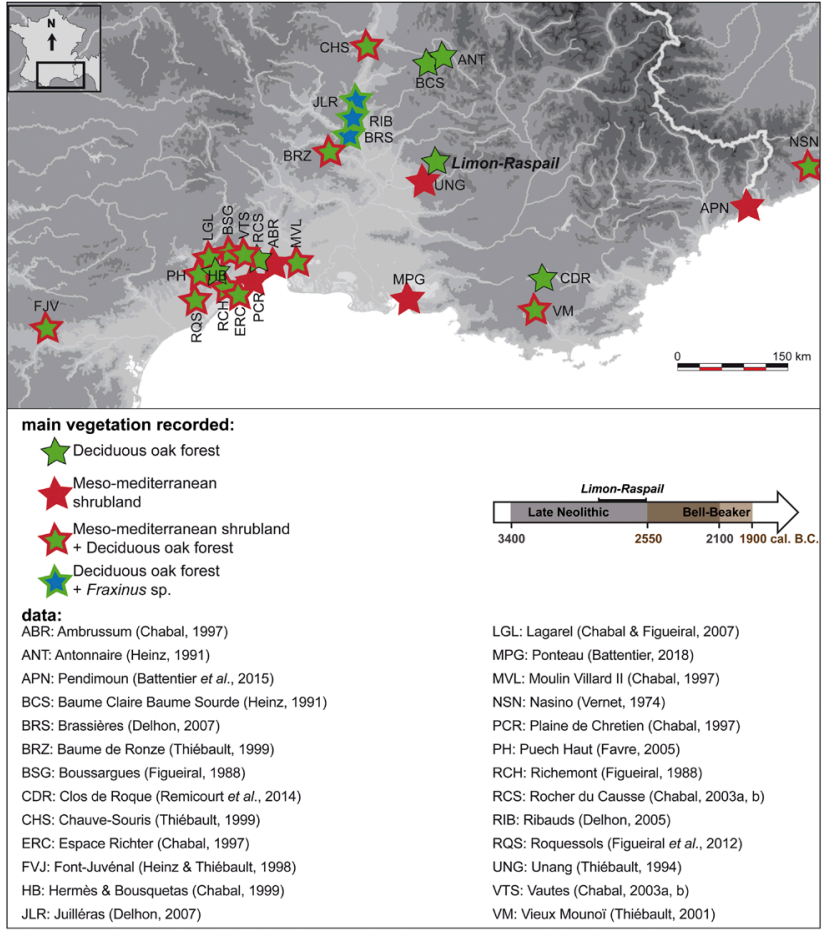

Figure 7: (See colour plate VIII) Dominant vegetal landscape in the Northwestern Mediterranean low lands according to charcoal data from archaeological sites which document the Late Neolithic period.

Figure 7: (Voir planche couleur VIII) Paysages végétaux prépondérants dans les basses terres de Méditerranée nord-occidentale, d'après les données anthracologiques de sites archéologiques qui documentent la période du Néolithique final.

seems to begin earlier than in the hinterland (Thiébault, 1991; Battentier, 2018). The North-western Mediterranean shoreline seems exploited for agro-pastoral purposes since the early phase of the Impresso-Cardial complex whereas, in the hinterland, the first Neolithic indicators only appear during the second phase of this complex (Binder \& Maggi, 2001; Binder, 2013; Binder \& Lepère, 2014).

The location of Limon-Raspail in the hinterland between the Rhone alluvial plain and the Alps foothills induces more temperate climatic conditions than on the shoreline and the topography allowed the development of a relatively deep soil, which favours a better resilience of the deciduous oak forest when it is submitted to anthropogenic disturbances. Even when the open vegetation taxa become more diverse in the charcoal spectra from Limon-Raspail, deciduous oak remains the most abundant species, in number of fragments and occurrences, in the pits. The climatic and edaphic characteristics of Limon-Raspail may explain the slight evolution of the vegetal dynamics toward more open landscapes, probably as a response to the anthropogenic pressure. The 
presence of Abies sp., a fire-sensitive taxon which currently belongs to the mountain vegetation belt and that was more widespread at lower altitude, in the north-western Mediterranean, before the rise of the anthropogenic impact according to pollen data (e.g. Muller et al., 2007; Cruise et al., 2009; Magri et al., 2015) suggests a relatively undisturbed vegetal cover.

In the lower layers of the pits, the low taxonomic diversity and the dominance of the deciduous oak may also reflect the environment when the first dwellers arrived to the site. Indeed, the exploitation of the tree cover, mainly represented by deciduous oak in the local vegetation, enables to generate open spaces thereby facilitating the establishment of the dwelling and the agro-pastoral activities. Then, the slight diversification of the charcoal spectra in the upper levels of the pits from Limon-Raspail may illustrate an enlargement of the fuel supply territory and/or an intensification and diversification of human activities, leading to a growing impact on the vegetation.

However, the charcoal spectrum from Limon-Raspail is relatively original among the Late Neolithic sites of Southern France. Most of the time, the meso-mediterranean shrubland is better represented in terms of percentage of fragments per taxa and the deciduous forest less predominant (Fig. 7). Considering the abundance of construction earth at Limon-Raspail and the large wattle imprints which suggest the presence of earthen and wooden architecture, we must consider the possibility that a part of the fragments identified originate from timber or at least from timber residues used as fuel. The hypothesis of the presence of timber among the charcoal assemblage is impossible to confirm because of the absence of burnt architecture remains in a primary position, which would have enabled a comparison between firewood and timber spectra. Nevertheless, the selection of deciduous oak for timber has been evidenced for the Neolithic of southern France, at Les Vautes (Chabal, 2003a, b), Cazan (Delhon et al., 2017) and probably Puech Haut (Fabre, 2005). The possibility that timber could end up in hearths together with wood especially gathered to be used as fuel has already been raised in particular for the Early Neolithic settlements in Belgium and for the Late Neolithic pile dwellings in Jura (North-western France) (Dufraisse, 2008; Salavert \& Dufraisse, 2014, Salavert et al., 2014). The re-use of timber as fuel or the incorporation of timber residues as firewood could induce an over-representation of deciduous oak, which would then partly reflect the selection of this specie for a specific use (timber) rather than the actual contribution of the different taxa to the woody vegetation around the site. Deciduous oak may have been selected because of its abundance in the local vegetation and because it fits some technical requirements thanks to its dimensions and because it is more or less rot-proof compared to other species.

\section{Conclusions}

The interpretation of anthracological data issued from short term accumulations, in pits with no information about the duration they recorded, is very challenging. Still, the high diversity of woody species at Limon-Raspail is relevant to suggest a mosaic vegetal landscape still dominated by the deciduous oak forest at the end of the Neolithic. In this area poorly documented for this period when the foreland is concerned by the shift from a wide-spread primary deciduous oak forest to a growing importance of evergreen shrublands, this result is yet of great interest. The cause of the slight increase of the sclerophyllous vegetation in the uppermost levels (ecological dynamic or socio-economical change?) is not easily identifiable, due to the nature of the data (charcoal accumulations without clear chronological relation) and the lack of comparative data. Despite the early agro-pastoral exploitation and the constant frequentation of the region throughout the Neolithic, climatic (edge of the Mediterranean influence), topographic or edaphic factors may have favoured a better resilience of the forest to the anthropogenic pressure than in foreland. The presence of Abies sp. suggests a relatively undisturbed vegetal cover. The charcoal analysis at Limon-Raspail is a first and promising step towards a better understanding of the Late Neolithic environment and its management, in the Mediterranean hinterland.

\section{Aknowledgements}

The authors are very grateful to the French Ministry of Culture, the LAMPEA Laboratory (CNRS - Aix Marseille Université) and the owner of the land, Claude Ughetto, for their logistical support during the Limon-Raspail excavation. We also thank Catherine Monziols for organising a visit of this area during the summer 2015 and Ingrid Beever for the linguistic revision. We wish to express our thanks to the Université Côte D'Azur which financed the Janet Battentier's thesis. We are thankful to our anonymous reviewers whose constructive suggestions have helped to improve this manuscript. 


\section{References}

Barbero, M., Quézel, P., 1975. Végétation culminale du Mont Ventoux - sa signification dans une interprétation phytogéographique des Préalpes Méridionales. Ecologia Mediterranea, 1:3-33.

Battentier, J., Thiébault, S., Binder, D., Théry-Parisot, I., Carré, A., Delhon, C., 2015. L'abri Pendimoun (Castellar, AlpesMaritimes) : nouvelles données sur l'évolution du couvert forestier et l'exploitation du milieu au Néolithique (5 800-2 000 ans cal. BCE). Quaternaire, 26, (4): 277-290.

Battentier, J., Binder, D., Maggi, R., Negrino, F., Sénépart, I., Tozzi, C., Théry-Parisot, I., Delhon, C., 2018. The environment of the last hunters-gatherers and first agropastoralists in the western Mediterranean region, between the Rhone and the Northern Apennines (7th-6th millennium cal. BCE): Attractiveness of the landscape units and settlement patterns. Quaternary Science Reviews, 184: 167-182.

Battentier, J., 2018. Gestion des espaces forestiers provençaux et ligures au Néolithique : approche anthracologique. Thèse de doctorat, Université Côte d'Azur, France.

Beeching, A., 2003. Mobilité et société néolithiques dans les Alpes occidentales et la France méridionale. Preistoria Alpina, 39: 175-187.

Binder, D., Maggi, R., 2001. Le Néolithique ancien de l'arc liguroprovençal. Bulletin de la Société Préhistorique Française, 98: 411-422.

Binder, D., Jallot, L., Thiébault, S., 2002. Les occupations néolithiques des Petites-Bâties (Lamotte-du-Rhône, Vaucluse). In Archéologie du TGV Méditerrannée (tome 1, la Préhistoire, fiches de synthèse). Monographies d'Archéologie Méditerranéenne, 8, Lattes, 103-122.

Binder, D., Sénépart, I., 2004. Derniers chasseurs et premiers paysans de Vaucluse. Mésolithique et Néolithique ancien : 7000-4700 av. J.-C. In A. Guilcher, J. Buisson-Catil, C. Hussy, M. Pagni, M. Olive (ed.). Vaucluse Préhistorique. Le territoire, les hommes, les cultures et les sites. Éditions A. Barthélemy, Le Pontet, 131-161.

Binder, D., Gratuze, B., Vaquer, J., 2012. La circulation de l'obsidienne dans le sud de la France au Néolithique. In M. Borrell, F. Borrel, J. Bosc, X. Clop, M. Molist (ed.). Networks in the Neolithic. Exchange of raw materials, products and ideas in the Western Mediterranean (VII-III millennium BC), Congrés Internacional Xarxes al Neolític (Gava, 2011). Rubricatum 5, Museu de Gavà, Gava - Bellaterra, 189-200.

Binder, D., 2013. Mésolithique et Néolithique ancien en Italie et dans le Sud-est de la France entre 7000 et 5500 BCE cal : questions ouvertes sur les dynamiques culturelles et les procès d'interaction. In T. Perrin, C. Manen, G. Marchand, P. Allard, D. Binder, M. Ilett (ed.). Transitions, ruptures et conti- nuité durant la Préhistoire, actes du XXVIIe congrès préhistorique de France (Bordeaux-Les Eyzies, 2010), Société préhistorique française, Paris, 341-355.

Binder, D., Lepère, C., 2014. Impresso-Cardial transition to SMP and Chassey in Provence. Rivista di Studi Liguri, LXXVIILXXIX : 21-29.

Blaise, E., 2005. Lélevage au Néolithique final dans le Sud-est de la France : éléments de réflexion sur la gestion des troupeaux. Anthropozoologica, 40 (1): 191-216.

Blaise, E., 2010. Économie animale et gestion des troupeaux au Néolithique final en Provence : approche archéozoologique et contribution des analyses isotopiques de l'émail dentaire. British Archaeological Reports International series 2080, Archaeopress, Oxford.

Bosquet, D., 2013. Chronological signification of Linear Pottery waste assemblages and waste management at the village scale. Spatial analysis of Remicourt "En Bia Flo" II (Liège province, Belgium). In C. Hamon, P. Allard, M. Ilett (ed.). The domestic Space in LBK Settlements. Arbeitsgemeinschaft. Internationale Archaölogie 17, Verlag Marie Leidorf GmbH, Rahden, 29-42. Bouville, C., 1980. La population préhistorique de Provence : aspect démographique du Chalcolithique. Bulletin Archéologique de Provence, 5-6: 38-45.

Brisset, É., Miramont, C., Guiter, F., Anthony, E. J., Tachikawa, K., Poulenard, J., Arnaud, F., Delhon, C., Meunier, J.-D., Bard, É., Suméra, F., 2013. Non-reversible geosystem destabilisation at $4200 \mathrm{cal}$. BP: Sedimentological, geochemical and botanical markers of soil erosion recorded in a Mediterranean alpine lake. The Holocene, 23 (12) : 1863-1874.

Buisson-Catil, J., 2001. Un gisement de plein air du Néolithique ancien à Céron (Vénasque, Vaucluse). Bulletin du groupe archéologique de Carpentras et de sa région, 12: 41-45.

Caraglio, A., 2015. Temps, espaces, dynamique de peuplement : la fin du Néolithique provençal. Thèse de doctorat, Université Aix-Marseille I, France.

Carmantrand, M. de, 1955. Le reboisement du mont Ventoux. Bulletin de la Société forestière de Franche-Comté.

Cauliez, J., 2011. Restitution des aires culturelles au Néolithique final dans le sud-est de la France. Dynamiques de formation et d'évolution des styles céramiques. Gallia Préhistoire, 53 : 85-202.

Cauliez, J., Blaise, E., Bressy, C., Convertini, F., Gilabert, C., Hamon, C., Lazard, N., Negroni, S., Ollivier, V., Pellissier, M., Pétrequin, P., Piatscheck, C., Provenzano, N., Renault, S., 2011. Le site du Limon-Raspail à Bédoin dans le Vaucluse et le Néolithique final de moyenne vallée du Rhône. Bulletin de la Société Préhistorique Française, 108: 263-330.

Chabal, L., 1997. Forêts et sociétés en Languedoc (Néolithique final, Antiquité tardive), l'anthracologie, méthode et paléoécologie. Documents d'Archéologie Française 63, Maison des Sciences de l'Homme, Paris. 
Chabal, L., 1999. Étude anthracologique de 13 sites du Biterrois et de la Vallée de l'Hérault, du Néolithique moyen au Moyen Âge central. In Études archéologiques sur le tracé du gazoduc artère du midi. Synthèses des travaux scientifiques. Document Final de Synthèse 14, AFAN, 163-193.

Chabal, L., 2003a. Le contexte forestier des Vautes au III ${ }^{\mathrm{e}}$ millénaire av. n. è. : étude anthracologique. In J. Guilaine, G. Escallon (ed.). Les Vautes (Saint-Gély-du-Fesc, Hérault) et le Néolithique final du Languedoc oriental. Recherches Archéologiques Préventives 2, Éditions Centre d'Anthropologie et Institut National de Recherches Archéologiques Préventives, Toulouse, 137-143.

Chabal, L., 2003b. L'environnement forestier au III ${ }^{\mathrm{e}}$ millénaire en Languedoc oriental. In J. Guilaine J, G. Escallon (ed.). Les Vautes (Saint-Gély-du-Fesc, Hérault) et le Néolithique final du Languedoc oriental. Recherche Archéologiques Préventives 2, Éditions Centre d'Anthropologie et Institut National de Recherches Archéologiques Préventives, Toulouse, 293-305.

Chabal, L., Figueiral, I., 2007. Approche paléoécologique du site de Lagarel d'après l'étude anthracologique : Néolithique ancien haut Moyen Âge. In O. Ginouvez (ed.). Le Lagarel, La moyenne vallée de l'Hérault durant la Préhistoire récente et les premiers siècles de notre ère. Autoroute A 750, Contournement de Saint-André-deSangonis (Hérault). Rapport final d'opération, INRAP, 99-101.

Courtin, J., 1974. Le Néolithique de la Provence. Mémoire de la Société Préhistorique Française 11, Klincksieck, Paris.

Cruise, G. M., Macphail, R. I., Linderholm, J., Maggi, R., Marshall, P. D., 2009. Lago di Bargone, Liguria, N Italy: a reconstruction of Holocene environmental and land-use history. The Holocene, 19 (7) : 987-1003.

D’Anna, A., Courtin, J., Coutel, R., Müller, A., 1989. Habitats perchés et enceintes du Néolithique final et Chalcolithique dans le Luberon central (Vaucluse). In A. D’Anna, X. Gutherz (ed.). Enceintes, Habitats ceinturés, sites perchés, du Néolithique au Bronze ancien dans le sud de la France et les régions voisines, Actes de la table ronde de Lattes et Aix-en-Provence (1987). Mémoire de la Société Languedocienne de Préhistoire 2, Société Languedocienne de Préhistoire et ADAPACA, Montpellier, 165-193.

D'Anna, A., 1995. Le Néolithique final en Provence, In J.-L. Voruz (ed.). Chronologies néolithiques. De 6000 à 2000 avant notre ère dans le Bassin rhodanien. Actes du Colloque d'Ambérieu-enBugey (1992). Documents du Département d'Anthropologie et d'Ecologie de l'université de Genève 20, Société Préhistorique Rhodanienne, Ambérieu-en-Bugey, 265-286.

Delhon, C., 2005. Anthropisation et paléoclimats du Tardiglaciaire à l'Holocène en moyenne vallée du Rhône : études pluridisciplinaires des spectres phytolithiques et pédo-anthracologiques de séquences naturelles et de sites archéologiques. Thèse de doctorat, Université Paris 1 Panthéon-Sorbonne, France.
Delhon, C., 2007. Phytolith and pedoanthracology analysis of "off-site" Holocene sequences from Mondragon (Middle Rhone Valley, south of France). In M. Madella, D. Zurro (ed.). Plants, People and Places: Recent Studies in Phytolithic Analysis. Oxbow Books, Oxford, 173-188.

Delhon, C., Thiébault, S., 2008. An approach to Holocene vegetation history in the middle Rhone valley (France): anthracological data from the "TGV-Mediterranée" excavations. British Archaeological Reports. International Series, 1807: 63-73.

Delhon, C., Thiébault, S., Berger, J.-F., 2009. Environment and landscape management during the Middle Neolithic in Southern France: evidences of agro-sylvo-pastoral systems in the middle Rhone valley. Quaternary International, 200: 50-65.

Delhon, C., 2016. Les assemblages de charbons en dépôts “concentrés" : une nouvelle méthode de calcul pour améliorer leur représentativité du bois mis au feu. ArcheoSciences, 40 : 7-15.

Delhon, C., Moreau, C., Magnin, F., Howarth, L., 2017. Rotten posts and selected fuel: Charcoal analysis of from the first Middle Neolithic village identified in Provence (Cazan-Le Clos du Moulin, Vernègues, Bouche-du-Rhône, South of France). Quaternary International, $458: 1-13$.

Delaunay, G., Ollivier, V., Müller, A., Martin, S., Guendon, J.-L., Blaise, E., Bourne, S., Gilabert, C., Pellissier, M., 2006. Le site Néolithique final du Verger (Le Mirail, Peypin d'Aigues, Vaucluse): une occupation en contexte travertineux : résultats des études paléoenvironnementales et du sondage archéologique 2003. In P. Fouéré, C. Chevillot, P. Courtaud, O. Ferullo, C. Leroyer (ed.). Paysages et peuplements : aspects culturels et chronologiques en France méridionale : actualité de la recherche, Actes des 6 e Rencontres Méridionales de Préhistoire Récente (Périgueux, 2004). ADRAHP-PSO, Cressensac, 113-124.

Digerfeldt, G., Beaulieu, J.-L. de, Guiot, J., Mouthon, J., 1997. Reconstruction and paleoclimatic interpretation of Holocene lake-level changes in Lac de Saint-Léger, HauteProvence, southeast France. Palaeogeography, Palaeoclimatology, Palaeoecology, 136: 231-258.

Dufraisse, A., 2008. Firewood management and woodland exploitation during the late Neolithic at Lac de Chalain (Jura, France). Vegetation History and Archeobotany, 17 (2): 199-210.

Escalon de Fonton, M., 1980. Informations archéologiques. Circonscription de Provence-Alpes-Côte-d'Azur. Gallia Préhistoire, 23, (2): 525-547.

Fabre, L., 2005. Charbons de bois et chrono-écologie des occupations du Puech Haut. In L. Carroza (ed.). La fin du Néolithique et les débuts de la métallurgie en Languedoc central. Les habitats de la colline du Puech Haut à Paulhan, Hérault. Archives d'Ecologie Préhistorique, Toulouse, 533-543.

Figueiral, I., 1988. Le Paysage végétal du Chalcolithique languedocien : étude anthracologique des gisements de Boussargues et 
Richemont. In T. Hackens, A. V. Munaut, C. Till (ed.). Wood and Archaeology, Bois et archéologie. First European Conference (Louvainla-Neuve, 1987). PACT 22, Louvain-la-Neuve, 259-269.

Figueiral, I., Fabre, L., Tardy, C., 2012. Charcoal analysis in the A750-A75 motorway (Clermont l'Hérault / Saint André de Sangonis - Béziers, southern France): a case-study in Preventive Archaeology. In E. Badal, Y. Carrión, M. Macías, M. Ntinou (ed.). Wood and charcoal evidence for human and natural history. Departament de Prehistòria i Arqueologia de la Universitat de València, València (Saguntum, extra 11) 105-114.

Gobert, J., Pautou, G. 1968. Carte de végétation Feuille XXXI40 - Vaison. Documents pour la carte de végétation des Alpes, 6.

Guende, G., Barbero, M., 1978. Sensibilité des milieux et impacts des activités humaines sur le Massif du Ventoux. Documents de cartographie écologique, 20: 41-60.

Hameau, P., Paccard, M., 1989. Un nouveau témoin de l'art schématique post-glaciaire : les abris Perrets (Blauvac, Vaucluse). Bulletin de la Société Préhistorique Française, 86, (4): 119-128.

Heinz, C., 1991. Upper Pleistocene and Holocene vegetation in the South of France and Andorra. Adaptations and first ruptures: new charcoal analysis data. Review of Palaeobotany and Palynology, 69: 299-324.

Heinz, C., Thiébault, S., Vernet, J.-L., 1993. Gestion et dégradation de la forêt préhistorique méditerranéenne. In J.-C. Blanchet, D. Mordant, A. Bulard, C. Constantin, J. Tarrete (ed.). Actes du XVIe colloque interrégional sur le Néolithique. Documents d'Archéologie Française, 39, Maison des Sciences de l'Homme, Paris, 12-18.

Heinz, C., Thiébault, S., 1998. Characterization and palaeoecological significance of archaeological charcoal assemblages during Late and Post-Glacial phases in southern France. Quaternary Research, 50, (1): 56-68.

Last, J., 1998. The residue of yesterday's existence: settlement space and discard at Miskovice and Bylany. Bylany Varia, 1: 17-46.

Léa, V., 2004. Centre de production et diffusion des silex bédouliens au Chasséen. Gallia Préhistoire, 46 : 231-250.

Léa, V., Georjon, C., Lepère, C., Sénépart, I., Thirault, E., 2004. Chasséen vauclusien qui es-tu ? In A. Guilcher, J. Buisson-Catil, C. Hussy, M. Pagni, M. Olive (ed.). Vaucluse Préhistorique. Le territoire, les hommes, les cultures et les sites. Éditions A. Barthélemy, Le Pontet, 165-200.

Léa, V., 2005. Raw, pre-heated or ready to use: discovering specialist supply systems for flint industries in mid-Neolithic (Chassey culture) communities in southern France. Antiquity, 79 (303): 51-65.

Léa, V., 2011. Malaucène, Saint-Martin, Vaucluse (84). Bilan scientifique de la région Provence-Alpes-Côte-D'azur, Service Régional de l'Archéologie, Aix-en-Provence, 220-221.

Lemercier, O., Berger, J.-F., Düh, P., Loirat, D., Lazard-Dhollande, N., Mellony, P., Nohe, A.-F., Pellissier, M., Renault, S., Seris,
D., Tcheremissinoff, Y., 2002. Les occupations néolithiques de Mondragon - Les Juilléras (Vaucluse). In Archéologie du TGV Méditerrannée (tome 1, la Préhistoire). Monographies d'Archéologie Méditerranéenne 8, Lattes, 147-172.

Lemercier, O., Blaise, E., Cauliez, J., Furestier, R., Gilabert, C., Lazard, N., Pinet, L., Provenzano, N., 2004. La fin des temps néolithiques. In A. Guilcher, J. Buisson-Catil, C. Hussy, M. Pagni, M. Olive (ed.). Vaucluse Préhistorique. Le territoire, les hommes, les cultures et les sites. Éditions A. Barthélemy, Le Pontet, 195-246.

Lemercier, O., Gilabert, C., 2009 Approche chronoculturelle de l'habitat de la fin du Néolithique en Provence. In A. Beeching, I. Sénépart (ed.). De la maison au village. L'habitat néolithique dans le Sud de la France et le Nord-Ouest méditerranéen, Actes de la table ronde des 23 et 24 mai 2003 (Marseille). Mémoire de la Société Préhistorique Française, 48, 255-266.

Magny, M., Vannière, B., Zanchetta, G., Fouache, É., Touchais, G., Petrika, L., Coussot, C., Walter-Simonnet, A.-V., Arnaud, F., 2009. Possible complexity of the climatic event around 4300-3800 cal. BP in the central and western Mediterranean. The Holocene 19 (6): 823-833.

Magri, D., Agrillo, E., Di Rita, F., Furlanetto, G., Pini, R., Ravazzi, C., Spada, F., 2015. Holocene dynamics of tree taxa populations in Italy. Review of Palaeobotany and Palynology, $218: 267-284$.

Mignon, J.-M., Margarit, X., Van Willigen, S., 2010. Vaison-laRomaine (84), le Petit Auzon II. Bilan scientifique de la région Provence-Alpes-Côte-D’azur, Service Régional de l'Archéologie, Aix-en-Provence, 240-241.

Müller, A., D'Anna, A., Brandi, R., Bretagne, P., Maurin, M., 1986. Le gisement de plein air Chalcolithique de la Plaine des Blancs à Courthézon, Vaucluse. Bulletin de la Société Préhistorique Française, 83, (11-12): 470-483.

Muller, S. D., Nakagawa, T., Beaulieu, J.-L. de, Court-Picon, M., Carcaillet, C., Miramont, C., Roiron, P., Boutterin, C., Ali, A. A., Bruneton, H., 2007. Postglacial migration of silver fir (Abies alba Mill.) in the south-western Alps. Journal of Biogeography, 34: 876-899.

Needham, S., Spence, T., 1997. Refuse and the formation of middens. Antiquity, 71: 77-90.

Paccard, M., Bouville, C., 1993. La Grotte d'Unang à Mallemortdu-Comtat, Avignon : service d'archéologie du Vaucluse. Documents d'archéologie Vauclusienne, 4: 1-205.

Rameau, J.-C., Mansion, D., Dume, G., Gauderville, C., 2008. Flore Forestière Française, t. 3 : région méditerranée. Institut pour le développement forestier, Paris.

Reimer, P.J., Bard, E., Bayliss, A., Beck, J.W., Blackwell, P. G., Bronk Ramsey, C., Buck, C. E., Cheng, H., Edwards, R. L., Friedrich, M., Grootes, P. M., Guilderson, T. P., Haflidason, H., Hadjdas, I., Hatte, C., Heaton, T. J., Hoffmann, D. L., Hogg, 
A.G., Hughen, K.A., Kaiser, K.F., Kromer, B., Manning, S.W., Niu, M., Reimer, R.W., Richards, D.A., Scott, E.M., Southon, J.R., Staff, R. A., Turney, C.S.M., Van Der Plicht, J., 2013. INTCAL13 and MARINE13 radiocarbon age calibration curves 0-50,000 years cal. BP. Radiocarbon, 55, (4): 1869-1887.

Remicourt, M., Andrieu-Ponel, V., Audibert, C., Baradat, A., Battentier, J., Blaise, E., Bonnardin, S., Caverne, J.-B., Fernandes, P., Furestier, R., Girard, B., Lachenal, T., Lepère, C., Locatelli, C., Martin, L., Parisot, N., Ponel, P., Pousset, D., Rué, M., Schmitt, A., Sénépart, I., Thirault, E., 2014. Les Occupations Pré et Protohistoriques Du Clos De Roque À Saint-Maximin-La-Sainte-Baume, Var. In I. Sénépart, F. Leandri, J. Cauliez, T. Perrin, E. Thirault (ed.). Chronologie de la Préhistoire récente dans le Sud de la France Actualité de la recherche. Actes des $10^{\mathrm{e}}$ Rencontres Méridionales de Préhistoire Récente (Porticcio, 2012). Archives d'Ecologie Préhistorique, Toulouse, 523-548.

Roqué-Rosell, J., Torchy, L., Roucau, C., Léa, V., Colomban, Ph., Regert, M., Binder, D., Pelegrin, J., Sciau, Ph., 2011. Influence of heat treatment on the physical transformations of flint used by Neolithic societies in the western Mediterranean. Materials Research Society proceedings in Art \& Archaeology, 1319, [http:// dx.doi.org/10.1557/opl.2011.926], $7^{\text {th }}$ march 2016.

Salavert, A., 2010. Apport de l'archéobotanique à la compréhension des sociétés néolithiques. Analyses anthracologiques et carpologiques de neuf sites rubanés de Moyenne-Belgique (5200-5000 av. J.-C.). Thèse de doctorat, Université de Paris I Panthéon-Sorbonne, France.

Salavert, A., Dufraisse, A., 2014. Understanding the impact of socio-economic activities on archaeological charcoal assemblages in temperate areas: A comparative analysis of firewood management in two Neolithic societies in Western Europe (Belgium, France). Journal of Anthropological Archaeology, 35: 153-163.

Salavert, A., Bosquet, D., Damblon, F., 2014. Natural woodland composition and vegetation dynamic during the Linearbandkeramik in north-western Europe (central Belgium, 5200-5000 BC). Journal of Archaeological science, 51: 84-93.

Sargiano, J.-P., Van Willigen, S., D’Anna, A., Renault, S., Hunger, K., Woerlesoares, M., Gaday, R., 2010. Les Bagnoles à l'Islesur-la-Sorgue (Vaucluse), aspects nouveaux dans le Néolithique moyen du midi de la France. Gallia Préhistoire, 52: 193-239.

Sauzade, G., Carry, A., Chambert, A., 1990. Un nouveau faciès du Néolithique final provençal : le groupe du Fraischamp. L'habitat de la Clairière à La-Roque-sur-Pernes (Vaucluse). Gallia Préhistoire, 32 : 151-178.

Schweingruber, F., 1990. Anatomie europäischer Hölzer-Anatomy of European woods. Haupt, Stuttgart.
Sénépart, I., 2009. L'habitat Néolithique ancien cardial du Baratin à Courthézon (Vaucluse). In A. Beeching, I. Sénépart (ed.). De la maison au village. L'habitat néolithique dans le Sud de la France et le Nord-Ouest méditerranéen, Actes de la table ronde des 23 et 24 mai 2003 (Marseille). Mémoire de la Société Préhistorique Française, 48: 23-30.

Shannon, C. E., 1948. A Mathematical Theory of Communication. The Bell System Technical Journal, 27 : 379-423, 623-656.

Shannon, C. E., Weaver, W., 1963. The Mathematical Theory of Communication. University of Illinois Press, Urbana.

Théry-Parisot, I., Chabal, L., Chrzavzez, J., 2010. Anthracology and taphonomy, from wood gathering to charcoal analysis. A review of the taphonomic processes modifying charcoal assemblages. Palaeogeography, Palaeoclimatology, Palaeoecology 291: 142-153.

Thiébault, S., 1991. Contribution de l'analyse anthracologique à la définition d'une identité du Chasséen. In A. Beeching, D. Binder, J.-C. Blanchet, C. Constantin, J. Dubouloz, R. Martinez, D. Mordant, J.-P. Thevenot, J. Vaquer (ed.). Identité du Chasséen, Actes du colloque de Nemours (1989). Mémoires du Musée de Préhistoire d'Ile de France, 4, APRAIF, Nemours, 369-377.

Thiébault, S., 1994. Résultats anthracologiques de la grotte d'Unang. In M. Paccard (ed.). La grotte d'Unang - Malemort du Comtat. Documents d'Archéologie Vauclusienne, 4: 192-194.

Thiébault, S., 1999. Dynamique des paysages et intervention humaine du Tardiglaciaire à l'Holocène, de la Méditerranée aux Préalpes sud-occidentales - apport de l'analyse anthracologique. Habilitation à Diriger des Recherches, Université Paris 1, France.

Thiébault, S., 2001. Anthracoanalyse des établissements néolithiques de la région liguro-provençale. Bulletin de la Société Préhistorique Française, 98, (3): 399-409.

Thinon, M., 2007. La végétation du mont Ventoux au cours des derniers millénaires, Forêt méditerranéenne, 28 (4) : 289-294.

Thirault, E., 2004. Echanges néolithiques : les haches alpines. Préhistoires, 10, Montagnac, Éditions Monique Mergoil.

Triat-Laval, H., 1979. Histoire de la forêt provençale depuis 15000 ans d'après l'analyse pollinique. Forêt méditerranéenne, 1: 19-24.

Vernet, J.-L., 1974. Précisions sur l'évolution de la végétation depuis le Tardiglaciaire dans la région méditerranéenne d'après les charbons de bois de l'Arma du Nasino (Savone-Italie). Bulletin de l'A.F.E.Q., 39: 65-72.

Vernet, J.-L., Thiébault, S., 1987. An approach to northwestern Mediterranean recent prehistoric vegetation and ecologic implications. Journal of Biogeography, 14, (2): 117-127.

Vernet, J.-L., Ogereau, P., Figueiral, I., Machado Yanes, C., Uzquiano, P., 2001. Guide d'identification des charbons de bois préhistoriques et récents. Sud-Ouest de l'Europe : France, Péninsule ibérique et Îles Canaries. Paris, CNRS Éditions. 